\title{
A DOCTOR'S CASH BOOK: THE ECONOMY OF GENERAL PRACTICE IN THE 1830 s
}

\author{
by
}

\section{S. L. LOUDON*}

THERE is, in the Warwick County Record Office, a pocket cash book measuring $5 \frac{3}{4} "$ by $3 \frac{3}{4} "$ in which entries were made from September 1828 to December 1831. The name "Henry Peart" is written on the flyleaf, and all that was known about him when the cash book was first seen was that it belonged to a medical man. Every entry in the book is financial: "cash received" on the left-hand pages, "cash paid" on the right. This cash book is, nevertheless, a manuscript of considerable interest; first, as a contribution to the social and economic history of the medical student and general practitioner in the period that it covers, and second, as an example of the historical value of such an apparently (at first sight) sparse document. An outline of the main events revealed by this cash book during the period of three and a quarter years is shown in Figure 1.

In September 1828, Peart came to London to study medicine: an entry to the effect that this was his "first winter session" suggests he had not studied medicine in London before. He obtained the Licence of the Society of Apothecaries in February 1829, paying the fee of six guineas, and the diploma of Membership of the Royal College of Surgeons of London in January 1830 , for a fee of $£ 22$. Unless he was a late starter in medicine, Peart was probably aged twenty-one at this time (and therefore born in 1807 or 1808), as this was the minimum age for entrance to these examinations. He clearly intended to become a general practitioner because the dual qualification MRCS and LSA was then the hallmark of this branch of the medical profession. ${ }^{2}$ Indeed, after 1 August 1815, the possession of the LSA was a legal requirement (quite often defied) while the MRCS was, as a contemporary put it, legally voluntary but conventionally compulsory. It seems likely that Peart travelled to London from Yorkshire, because there is an entry at the beginning of the book of a fare of $2 s .6 d$. to York and $£ 15 s .0 d$. to London. Moreover, in April 1829, he returned to Pocklington for the summer and, as his expenses were minimal, it was a reasonable assumption that he stayed with his family in Yorkshire. A selection from the main items of expenditure in the cash book

* I. S. L. Loudon, DM, FRCGP, Wellcome Research Fellow, Wellcome Unit for the History of Medicine, University of Oxford, 47 Banbury Road, Oxford OX2 6PE.

1 Warwickshire County Record Office, Cape Road, Warwick (Ref. CR 1840).

${ }^{2}$ I. S. L. Loudon, 'Two thousand medical men in 1847', Bull. Soc. Social Hist. Med., 1983, in press. The term "General Practitioner" came into being in the second and third decades of the nineteenth century. It was a term embracing the apothecary, the surgeon apothecary, and some with medical degrees from universities (mostly from Edinburgh) who identified themselves as a new and distinct group, quite separate from the physicians and the "pure" surgeons who practised surgery only. 


\section{S. L. Loudon}

is shown in Tables 1 and 2. The largest personal and domestic expense was lodgings, which varied from sixteen to eighteen shillings a week in London, depending, it seems, on whether he took his dinner in or out. Drinking coffee seems to have been his main luxury, and he paid for ale and tobacco occasionally, suggesting that he had abstemious habits. The costs of his medical education are shown in Table 2, but it is probable that he had already acquired some medical books and instruments before he came to London. In order to sit for the licence of the Society of Apothecaries he would have had to have spent five years as an apprentice, and six months at least at a hospital or dispensary - the latter, probably, in the provinces. ${ }^{3}$

FIGURE 1. MAIN EVENTS OF HENRY PEART'S LIFE FROM SEPTEMBER 1828 TO DECEMBER 1831
$1828 \int_{- \text {Seb. }}^{\text {Sept. }}$
Came to London for the final part of his medical education, travelling from York.
Obtained his Licence of the Society of Apothecaries (LSA).
At the end of the first winter session in London returned to Yorkshire to stay with his family in Pocklington.
Returned to London via Birmingham and Wolverhampton for the second winter session.
Obtained the diploma of the Royal College of Surgeons of London (MRCS).
Left for Paris via Dover and Calais.
Returned to England and travelled to York.
Left York and travelled to the Midlands via Birmingham and Wolverhampton and set up in general practice in Feckenham in Worcestershire.

\footnotetext{
${ }^{3}$ In October 1829, the period of attendance at a hospital or dispensary was increased from six months to a year.
} 
Henry Peart estimated the total expenses for the period September 1828 to January 1830 as follows:

September 1828-April 1829

First winter session in London

$\{1303 s .6 d$.

April 1829-September 1829

At home in Pocklington

$£ 130$ s. $0 d$.

September 1829-January 1830

Second winter session in London

$£ 676 s .6 d$.

Total

$£ 21010$ s. $0 d$.

There are no data for estimating the cost of his medical education before he came to London, but it would be usual for a student to have paid an apprenticeship premium of at least $£ 100$, and quite possibly $£ 200$. Other expenses would have included fees to a hospital or dispensary. The whole of his medical education would probably have cost $£ 500$, and it may well have been more.

TABLE 1. DOMESTIC AND PERSONAL EXPENSES WHILE A MEDICAL STUDENT IN LONDON 1828 AND 1829

Lodgings
Dinner
Coffee
Ale for dinner
Snuff
Cigars
Physic
Ointment
Linen
2 Neckerchiefs, black
Coat mending
Hat
Gaiters
Gloves
Haircutting
Zoological gardens
Pantomime
Covent Garden
Drury Lane
Adelphi
Sadlers Wells
English Opera
Tower of London

16s. to $18 s$. Weekly

$11 d$. to $2 s$. Once or twice a week

$7 \frac{1}{2} d$. to $1 s$. Several times a week

4d. to $6 d$. Once or twice a week

$1 \frac{1}{2} d$. Occasionally

10d. Occasionally

$\begin{array}{rc}6 d . & \text { Once } \\ 8 d . & \text { Once } \\ 5 s . & \text { Once } \\ 1 G n . & " \\ 2 d . & " \\ \text { f1 } 7 s .0 d . & " \\ 7 s . & " \\ 3 s .6 d . & " \\ 1 s . & \text { Every two months } \\ 1 s . & \text { Once } \\ 2 s . & " \\ 4 s . & " \\ 3 s .6 d . & " \\ 2 s . & " \\ 1 s . & " \\ 2 s . & " \\ 3 s . & "\end{array}$




\section{S. L. Loudon}

What can we deduce about his character? Unless he deliberately excluded all evidence of a profligate life from his cash book, we can guess that he was meticulous to the point of being fussy (from the detailed entries in the cash book), quiet (no evidence of entertaining friends), abstemious (occasional ale only), economical but not desperately short of money (visits to the theatre and the zoo), and probably studious, for he passed his examinations at the first attempt, bought medical books, and spent nearly two pounds on a French dictionary and other French books in preparation for a trip to Paris. Thus he does not conform to the popular stereotype of the medical student of the period, coarse, rough, brutal, lazy, hard-drinking, and extravagant. ${ }^{4}$

On 25 January 1830, he left for Paris. The habit of going abroad for further medical education was quite common and it was not expensive. London to Dover cost $18 s$., Dover to Calais 10s., 6d., and Calais to Paris ("Fare, eating etc:") $£ 218 s .3 \frac{1}{2} d$. Once in France, he recorded his expenses in francs, noting that the exchange rate was F25.50 to the pound. From the entries in the book it seems that the main purpose of going to Paris was to study medicine rather than mere pleasure. He recorded only two visits to the theatre and a visit to the "Hospital des Invalides and the Chambre of Deputies" [sic]. Food, drink, and lodging seem to have cost about the same in Paris as in London, but the costs of medical education, shown in Table 2, were less. While in Paris he went regularly to chapel and donated 50 centimes. While in London he also attended "Catholic chapel", donating $1 s$., and he attended chapel regularly in the place where he eventually settled. Moreover, the place his family lived in and the area he chose to practise in were both strongholds of Roman Catholicism, so that it seems reasonable to assume that he was a Catholic. Perhaps piety should be added to his other characteristics.

On 2 April 1830, Henry Peart travelled back to England via Calais and Dover, and arrived in York with eight shillings in his pocket. The total cost of his ten weeks in Paris (including fares) was $£ 4317 \mathrm{~s}$. $0 \mathrm{~d}$. On $15 \mathrm{June}$ 1830, he travelled from York to Birmingham, and ten days later to Wolverhampton. The cash book gives no clue where he settled except that it was somewhere in the Midlands and near Birmingham. $\mathrm{He}$ had, in fact, returned to London from York in September 1829 via Birmingham and Wolverhampton (deduced from entries about fares) and therefore may have had family or friends in the Midlands which induced him to choose this as a place to live. From June 1830 onwards, the entries on the right-hand pages are all concerned with furnishing a house and with small details of domestic expenditure. The purchase of food, coals, candles, and household goods of various sorts are painstakingly entered. Two entries: "woman", for $1 s$. and $6 d$. respectively, suggest occasional domestic help rather than a regularly employed domestic servant. Not until February 1831 is there an entry for clothes when he paid a tailor $£ 113 s$. $0 d$. for a "pair of trowsers", $£ 316 s$. $0 d$. for a coat, black, and $14 s$. $6 d$. for a waistcoat. There were no luxuries of any kind. Occasionally, he hired a horse for a few shillings, but the only regular entry is two shillings paid weekly to "boy in surgery". His weekly expenses for food, etc., about three pounds when he first arrived in the Midlands, were rapidly reduced to between a pound and $£ 110 s .0 d$. a week, but he still contributed $2 s .6 d$. most weeks to "chapel".

4 E. S. Turner, Call the doctor: a social history of medical men, London, Michael Joseph, 1958. 


\section{TABLE 2. THE EXPENSES OF MEDICAL EDUCATION AND EQUIPMENT IN} LONDON AND PARIS

\begin{tabular}{|c|c|c|c|c|c|c|c|}
\hline LONDON $1828-1829$ & & & $P A R$ & $S 1830$ & & & \\
\hline BOOKS & ⿷ $s$. & d. & & Francs & & s. & $d .^{*}$ \\
\hline Potts surgery & 4 & & Sabatier's surgery & 6.0 & & 4 & 8 \\
\hline Celsus & 5 & & Laennec's auscultation & 18.0 & & 14 & 1 \\
\hline Dictionary & 3 & & Ratier's formula & 4.25 & & 3 & 4 \\
\hline Paris' Pharm. & 10 & & & & & & \\
\hline Periera's chemistry & $3 \mathrm{Gns}$ & & & & & & \\
\hline Books, French & 116 & 0 & & & & & \\
\hline Dictionary French & 3 & & & & & & \\
\hline LECTURES & & & & & & & \\
\hline Perpetual anatomy & $5 \mathrm{Gns}$ & & Course of operative & & & & \\
\hline Perpetual surgery & $5 \mathrm{Gns}$ & & surgery & 25.0 & & 19 & 5 \\
\hline Sir Astley Cooper: lecture & 16 & 6 & & & & & \\
\hline Periera & $4 \mathrm{Gns}$ & & & & & & \\
\hline Clutterbuck & $4 \mathrm{Gns}$ & & & & & & \\
\hline Waller & $5 \mathrm{Gns}$ & & & & & & \\
\hline Abernethy & $5 \mathrm{Gns}$ & & & & & & \\
\hline PRACTICAL WORK & & & & & & & \\
\hline Hospital & $18 \mathrm{Gns}$ & & & & & & \\
\hline Femur and crus & 16 & 3 & Two skulls & 35.0 & 1 & 7 & 5 \\
\hline An injected leg & 18 & 3 & Part of a subject & 1.0 & & & 9 \\
\hline do head and neck & 18 & 3 & & & & & \\
\hline do abdomen & 18 & 3 & & & & & \\
\hline Course of dissections & $3 \mathrm{Gns}$ & & $\begin{array}{l}\text { Entrance to dissecting } \\
\text { room }\end{array}$ & 1.0 & & & 9 \\
\hline INSTRUMENTS & & & & & & & \\
\hline Catheter & 7 & 6 & Lithotomy forceps & 3.0 & & 2 & 4 \\
\hline Medicine chest & 114 & 0 & Dissecting knives & 3.10 & & 2 & 8 \\
\hline Dissecting scissors & 5 & & Blizard's knife & 6.0 & & 4 & 8 \\
\hline Phosphorus & 1 & 6 & Deschamp's needle & 2.0 & & 1 & $6 \frac{1}{2}$ \\
\hline & & & 20 sounds & 4.93 & & & $10^{6}$ \\
\hline & & & Amputating knife & 8.0 & & 6 & 3 \\
\hline EXAMINATION FEES & & & & & & & \\
\hline Apothecaries Cert: & $6 \mathrm{Gns}$ & & & & & & \\
\hline College of Surgeons' & & & & & & & \\
\hline $\begin{array}{l}\text { diploma } \\
\text { fee for same }\end{array}$ & 220 & 0 & & & & & \\
\hline & & & ${ }^{*}$ Rate of exchange F2s & 0 to $£ 1$ & & & \\
\hline
\end{tabular}

The entries in the cash book during this period, and the manner in which they are entered, leave a strong impression that it was a period of financial anxiety when he was having to live more frugally than he had as a student in London.

The impression of poverty is confirmed by the evidence of his income during this period, although there is some uncertainty. It would have been customary for a general practitioner to keep a separate account book in which he entered visits made and medicine dispensed, and it is difficult to believe that Henry Peart with his meticulous habits failed to keep such a book. But the entries under "cash received" in the cash book seem to correspond to the bills he was paid by his patients, and it is clear 


\section{S. L. Loudon}

that, if it had not been for continued support from his family, he would not have survived. This is shown by the total income for two periods of six months: first, the initial six months in practice, and second, the same period the following year.

Total number of bills paid

Total amount received from these bills

Salary as parish medical officer for three months

Money received from his family
15 June 1830

to

30 Dec. 1830

12

$£ 418 s .0 d$.

$£ 1837 s . \overline{2 d}$.
I July 1831 to

31 Dec. 1831

£169s. 9 d.

$£ 1210$ s. $0 d$.

$£ 510$ s. $0 d$.

In 1830 , the amount he received from his family was $£ 2037 s .2 d$. and in $1831, £ 1615 s$. 0d. During his first eighteen months in practice, his total income as a general practitioner was only $£ 5215 s$. $7 d$. It is likely that the total amount paid by his family for the medical education of Henry Peart, and for supporting him when he started in general practice, even if no further payments were made after December 1831, was not less than $£ 900$ and probably over $£ 1,000$. The contrast between this cost and the income in provincial medical practice is vivid.

Subsequent searches have added little to the history of Henry Peart, but tended to confirm the assumption based on his cash book. He was, indeed, born in York in 1808. He practised in Feckenham, a district with a population of 3,254 in $1851^{\text {s }}$ rising to 3,850 in 1871 , close to the Warwickshire-Worcestershire border and about sixteen miles south-south-west of Birmingham. Peart was medical officer to the Feckenham branch of the Alcester Poor Law Union from 1844 to 1853, and there were two surgeons in Feckenham in the 1850 s - Henry Peart and W. J. Leacroft. ${ }^{6}$ The medical directory for 1847 includes the entry:

PEART, Henry, Feckenham, Worcestershire. Gen: Pract: MRCS 1830, LSA 1829. Surgeon to the Alcester Union.?

Henry Peart's death on 6 March 1867 at the age of fifty-nine ("for thirty four years surgeon in Feckenham; highly respected and deeply lamented by a wide circle of friends") is recorded in the death notices of Berrow's Worcester Journal for Saturday 16 March 1867. There is no mention of a widow or of children. There was no obituary notice either in the local press or in the medical press. His name does not appear in the lists of members of the Provincial Medical and Surgical Association, founded during his early days in practice only a few miles away. He appears to have been an inconspicuous general practitioner, probably unknown outside the confines of his practice.

\footnotetext{
'Population census for 1851.

- Cassey's Directory of Worcestershire for 1850, Billing's Directory of Worcestershire for 1855, and Kelly's Directory of Worcestershire for 1867.

'John Churchill's The London and Provincial Medical Directory for 1847 and subsequent years.
} 
Our knowledge of early nineteenth-century medical men is biased towards those whose lives and careers were recorded because they were, to a greater or lesser extent, distinguished men. The large majority of medical men - the undistinguished general practitioners, of whom, it seems, Henry Peart was one - seldom left any trace of their training or their work, however worthy they may have been within the limits of their practice. It is precisely for this reason, perhaps too obvious to need stating, that the cash book described here is so valuable; it provides documentary evidence of certain features of routine country practice in the 1830 s not widely recognized, although they were emphasized repeatedly in the substantial literature on medical reform in the first half of the nineteenth century. Three inter-related features, which were the source of frequent comment, were: (1) the expense of medical education; (2) the overcrowding of the medical profession in the period following the Apothecaries' Act of 1815; (3) the low income of country general practitioners and the difficulty of becoming established in practice.

The dual qualification for general practice, the MRCS and the LSA, (known at the time as "College and Hall") represented a great advance in medical education and contributed to the sense of corporate identity and new pride in their abilities that were so characteristic of the general practitioners of the 1820 s and 1830 s. Some historians have hailed the Apothecaries' Act of 1815 as an unqualified success; ${ }^{8}$ others, in particular Holloway, ${ }^{9}$ have seen it much more as an Act that pleased no one at the time and resulted only in the debasement of the general practitioner by the tyranny of the College of Physicians. It is certainly true that the Act in its final form was an emasculated version of a much better, comprehensive and far-sighted Bill drawn up by the Associated Apothecaries and Surgeon Apothecaries in 1812-13. ${ }^{10}$ The diploma of membership of the College of Surgeons was, perhaps, even more deserving of criticism. For many years the College (and previously the Company) of Surgeons had done little or nothing about education, believing that if they held an examination, education could be left to look after itself." But the examination, even in the $1830 \mathrm{~s}$, was at best a "superficial affair", 12 and when the cost of the diploma was raised in 1816 to $£ 32$ for those living within seven miles of London, and $£ 22$ for those outside this limit, it was far too expensive. ${ }^{13}$ The result of the dual qualification was, therefore,

\footnotetext{
For example, C. Newman, The evolution of medical education in the nineteenth century, London, Oxford University Press, 1957.

'S. W. F. Holloway, 'The Apothecaries' Act, 1815, part I: the origin of the Act', Med. Hist., 1966, 10: 107-129, and 'The Apothecaries' Act 1815, part II: the consequences of the Act', ibid., pp. 221-236. Not all general practitioners in the 1820 s were hostile to the Apothecaries' Act: see R. T. Webb, Lancet, 1828-9, i, 190-191.

${ }^{10}$ Transactions of the Associated Apothecaries and Surgeon Apothecaries, 1823, 1.

${ }^{11}$ Bernice Hamilton, 'The medical professions in the eighteenth century', Econ. Hist. Rev., 1951, 4: 141-169.

12 Analytical review: 'Letters to the President of the Associated Apothecaries and Surgeon Apothecaries of England and Wales', Med.-chir. Rev., 1820, 1: 204-208. See also 'A subscriber', Lancet, 1841-2, ii: 489, who wrote that the MRCS was worth so little that the LSA alone was proof of adequate instruction in surgery.

13 'Observations on the projected bill for restricting the practice of surgery and midwifery to Members of the Royal Colleges', Med. phys. J., 1816, 35: 146-151. 'Observations on the present system of medical
} 


\section{S. L. Loudon}

to raise quite suddenly and extensively, not only the standard but also the expense of medical education.

Before 1815, the country practitioner (the village apothecary or surgeon apothecary) could set up in practice after an apprenticeship, although some spent a year as a pupil at a provincial infirmary such as Bristol. After 1 August 1815, there was a compulsory five-year apprenticeship and a period of attendance both at lectures and at a hospital or dispensary. The College of Surgeons arranged the conditions for taking the diploma so that the candidate was forced to attend and pay heavy fees to one of the small but powerful group of London teaching hospitals. Moreover, the post-apprenticeship curriculum for both "College and Hall" was progressively increased in the years following the Act of 1815. This represented such an advance in education that a physician, E. J. Seymour, felt able to state in 1834, "the education of the general practitioner is of the very highest kind: I should say as good as that of physicians some years ago", 14 and the Gazette of Health, the champion of general practitioners and enemy of physicians, proclaimed in 1821 the superiority of the surgeon-apothecary over the physician. ${ }^{15}$ Another physician, Neil Arnott, believed, however, that "so much time and money was wasted" in the education of the general practitioner that the expense of the whole business was too high for the rewards of country practice. ${ }^{16}$ Indeed, one fear that was often expressed was that those who could afford the expense might well have higher professional ambitions than provincial general practice, while those who would be content with such a career might find the expense beyond them. If so, the danger was "the transfer of the cheapest practice entirely to irregular and uneducated practitioners". ${ }^{17}$

To what extent were the expenses recorded by Henry Peart and summarized in Tables 1 and 2 typical of the time? Evidence was provided by several witnesses at the Select Committee on Medical Education (1834) about the cost of general practitioners' medical education. Benjamin Travers believed it was possible to complete the time in London, including "board and lodging", for less than $£ 200 .{ }^{18} \mathrm{~J}$. H. Green thought the total figure, including apprenticeship, would be in the region of $£ 300,19$ but $R$. D. Grainger doubted if the total cost would ever be less than $£ 450-£ 500 .{ }^{20}$ The latter corresponds to our estimate for Henry Peart. In spite of the

education with a view to medical reform', by 'A Licentiate of the Royal College of Physicians of London', Med. quart. Rev., 1834, 2: 391-393.

${ }^{14}$ The Report of the Select Committee on Medical Education (PP 1834, XIII) Part I, Q.1060. See also, Lancet, 1836-7, i: 77, in which Professor Thompson states that the "education which formerly was confined to the physician has been extended to the general practitioner, and has been made more valuable by having engrafted on it, a knowledge of surgery"; and ibid., 1839-40, ii: 63, in which a correspondent asserted that the general practitioner was the equal, if not the superior to, the physician and "pure" surgeon, and in cases of difficulty general practitioners should call each other in, in consultation.

15 'The state of medicine in Great Britain', Gazette of Health, 1821, 5: 545-552.

${ }^{16}$ Select Committee on Medical Education, (PP 1834, XIII) Part I, Q.2461.

${ }^{17}$ Ibid., Part I, Q.2143 and Part III, Q.316.

18 Ibid., Part II, Q.5827:-8.

19 Ibid., Part II, Q.6485-6.

${ }^{20}$ Ibid., Part II, Q.6654. Also J. C. Hudson, The parent's hand-book-or, guide to the choice of employments, professions, etc., London, 1842, p. 89. Here the author states that the expense of qualifying a young man for general practice is about $£ 130$, "independently of his board, lodging, clothing etc: for five years, which will make the whole charge exceed five hundred pounds, towards which the pupil cannot earn a shilling". 
substantial cost, however, there was no lack of recruits to the ranks of general practice, and as early as the 1820 s there were constant complaints that the profession was overcrowded. ${ }^{21}$ Such complaints were so commonly expressed in a number of professions during the nineteenth century that they must be regarded with caution, ${ }^{22}$ but there were particular reasons for believing that overcrowding in medicine was true, and not a myth, during the years following 1815. One reason was the end of the Napoleonic wars.

Three hundred young practitioners were recruited annually during the latter years of the wars by the Navy and Army, the majority of whom were subsequently discharged to make their way in civilian practice. At the same time "the increased intelligence and wealth of the middle classes" induced them to put their sons through "a more liberal education" in order to join the ranks of the professions. ${ }^{23}$ The rise of the general practitioner was attributed to the rising number of middle-class families who "had long wished for a class of the faculty to whom they could apply with confidence in any description of case in which medical or surgical aid was necessary". ${ }^{24}$ The same families produced the abundance of ambitious young men who set their hearts on a career in medicine, and the Society of Apothecaries carried out the licensing duties imposed on them with such efficiency that between 1815 and 1833 they had examined 6,489 candidates, and passed 5,769 of them. ${ }^{25}$ In 1834, it was estimated that there were between 12,000 and 14,000 general practitioners in England and Wales ${ }^{26}$ when the population was about 14 million, so that the ratio of general practitioners to population was about $1: 1,000$ compared to $1: 2,280$ in 1974 . This, however, is an overestimate of the population available in 1834 to pay general practitioners. At the upper end of the social scale most families employed physicians as their family doctors, while at the lower end the much more numerous labouring poor received primary care on a large scale from the hospitals and dispensaries. ${ }^{27}$

\footnotetext{
21 'Observations on the proposed Surgeon's Bill', Lond. med. Repos. 1821, 15: 498-508: "That there has been an excess of practitioners, has been so notorious, that the parents of well-educated youths have for many years past preferred placing their sons in merchants and bankers' counting-houses, rather than devote them to a profession wherein success, owing to the number of competitors, is so precarious". See also, Quart. Rev., 1840, 67: 53-79: "The supply of medical practitioners is in fact not only very much beyond the demand, but very much beyond what is necessary to ensure a just and useful degree of competition".

${ }^{22} \mathrm{~F}$. Musgrove, 'Middle-class education and employment in the nineteenth century', Econ. Hist. Rev., 1959-60, n.s. 12: $99-111$.

${ }^{23} \mathrm{~J}$. H. Black, 'On the medical profession and its reform', Prov. med. surg. J., 1840-1, 1: 147-149. See also, 'Thoughts on the real and imaginary grievances of the medical profession', Lancet, 1841-2, ii: 778: "The augmented wealth of the nation, and the consequently increased facilities for obtaining a medical education, have raised the primary practitioner to a level in point of general acquirement and professional skill, with the obsolete surgical or medical referee".

$24 \mathrm{~J}$. C. Yeatman, 'Remarks on the profession of medicine in Sicily: an exposition on the principal evils to which it is subject in Great Britain: and observations on medical reform', Med. phys. J., 1815, 34: 186-193. See also, 'Medical reform', Morning Chronicle, 6 and 12 March 1841, reprinted in Prov. med. surg. J., $1841,2: 151-155$, "The public stood in need of a general practitioner - that is, of one who could officiate in all the departments of the profession, and dispense medicines as well as prescribe. This species of practitioner, which had sprung up insensibly, got to such an extent, that the formal recognition of this new department became indispensable".

${ }^{25}$ Records of the Society of Apothecaries, Guildhall Library London, MS 8211/1.

${ }^{26}$ Select Committee on Medical Education (PP 1834, XIII) Part III, Q.1003-5.

${ }^{27}$ I. S. L. Loudon, 'The origins and growth of the dispensary movement in England', Bull. Hist. Med., 1981, 55: 322-342.
} 


\section{S. L. Loudon}

It is hardly surprising that young practitioners such as Henry Peart experienced difficulty in establishing themselves in practice. But when they had been established for a year or two, what income did general practitioners earn in the first half of the nineteenth century? This is a question that is very difficult to answer. Evidence on incomes is sparse, and what there is suggests a range that was very wide indeed. ${ }^{28}$ Probably the range of incomes was wider in city than country practice. One observer remarked in 1834, "In the same locality we can see two general practitioners - one driving furiously from square to square - from nobleman to nobleman, the other eking out a wretched revenue by selling matches, cold cream and Morrison's pills; yet the rank and education are the same". ${ }^{29}$ Richard Smith junior (1772-1843), surgeon to the Bristol Infirmary, left manuscript accounts of the careers and sometimes the incomes of a large number of practitioners in and around Bristol during the eighteenth and early nineteenth centuries. ${ }^{30}$ They illustrate the difficulties and variable rewards of provincial general practice. Richard Edgell, for instance, born in 1776, was a Bristol city practitioner who achieved an income of $£ 1,500$ a year in 1828 at the age of fortyseven, but only after a long struggle and an income of $£ 380$ p.a. five years earlier. ${ }^{31}$ Another general practitioner, James Monday, born in Bristol in 1797, was a pupil at the Infirmary where all the surgeons thought highly of him. He obtained the LSA in 1819 but failed to establish himself in Bristol in 1820:

In January 1820 he put his name on a door but doing nothing he left it in August - he then went to South Petherton where he gave $£ 50$ to a practitioner whose name was Trowler but he earned only $£ 40$ a year.

[At Petherton] ... he found Mr Davis and Mr Norris, and after the death of Dr Prout two or three more came - Jolliffe Bernard and Wills being there already - two miles off is Martock, where Fry, Chaffey and Hamlin practise - and Ilminster 5 miles off are the two Clarkes ... but little hope therefore appeared that his prospect would mend and in consequence he quitted it... . In 1822 he went to succeed Mr Howell at Olveston giving the widow a hundred pounds for goodwill - in about a year he married her. ${ }^{32}$

Here, James Monday settled permanently, for he appears in practice at Olveston in the Medical Directory for 1847 . Incomes could vary quite widely in the country, but high incomes in the region of $£ 1,000$ per year must have been rare. Charles Price (born c. 1793) settled in Congresbury and earned only $f 120$ p.a. in the first twelve years, although he claimed to have attended 3,000 deliveries during that period. ${ }^{33}$ Trevor Morris, born in Chepstow in 1796, settled there in a good practice in the 1820s and earned $£ 400$ a year. ${ }^{34}$ Valentine Baker Webb, born in Bristol in 1802, was admitted MRCS in 1824 and attempted to set up in Bristol in 1825 and Bath in 1826, but failed in both cities. He went to Maesteg and, because private practice paid so little in South

\footnotetext{
${ }^{28}$ An exceptional example was provided by R. R. Pennington (b. 1761) of Portman Square, London, who was reputed to have earned up to $£ 10,000$ a year and boasted of having attended every member of the cabinet and every judge upon the bench. He was, significantly, famous for the vast quantities of medicine he prescribed. In his eighties he became the first president of the National Association of General Practitioners, J. F. Clarke, Autobiographical recollections of the medical profession, London, Churchill, 1874.

29 'Medical statistics and reform', Med.-chir. Rev., 1834, 20: 567-571.

${ }^{30}$ Bristol Royal Infirmary: biographical memoirs. Bristol Record Office, The Council House, Bristol.

${ }^{31}$ Ibid., IV, p. 350.

32 Ibid., XII, p. 206.

${ }^{33}$ Ibid., IX, p. 416.

${ }^{34}$ Ibid., IX, p. 408.
} 
Wales in 1830 , accepted the post of medical officer to a colliery at $£ 50-£ 60$ p.a. In 1836, he was in practice in Bibury, in 1837 in Cirencester, and in September 1837 he gave up the practice of medicine altogether. ${ }^{35}$ Thomas Wade Smith (born near Chepstow in 1797) "went into partnership with Mr Sweeting of Stroud whose business was considered to be worth $£ 1,200$ a year". ${ }^{36}$ Although a majority of the general practitioners whose brief biographies are included in the Bristol memoirs succeeded in becoming established in practice sooner or later (and the incomes of most were not recorded), about one in nine failed through poverty or drink or (in two instances) criminal activity. Where income was revealed, the most successful from the financial point of view was Richard Edgell, mentioned above.

The range of incomes, from $£ 50$ p.a. to (exceptionally) $£ 1,000$ p.a., suggests that provincial general practice was a variable and uncertain branch of the profession in the first half of the nineteenth century. By comparison, the prospects of the physician and surgeon with an honorary appointment at a voluntary hospital were good. The income of Andrew Carrick (1767-1837) MD Edinburgh and physician to the Bristol Infirmary, who was a physician of no more than average ability and renown, is shown in Table 3.37 Neil Arnott, a physician, acknowledged in 1834 that the country practitioner received a very low income but believed that most would be content with $£ 80-£ 90$ a year if they felt they belonged "to an honourable body like a curate ... much of the reward would be the station which the profession gave in society". ${ }^{38}$ Hudson wrote in 1842 that a "moderate general practitioner in London" earned $£ 300-\$ 400$ a year. $^{39}$ In the country it seems likely that the "moderate general practitioner" would earn between $£ 150-£ 200$, but as we have seen, some earned even less. Henry Holland, FRCP, in his evidence to the Select Committee on Medical

TABLE 3. THE INCOME OF A BRISTOL PHYSICIAN: ANDREW CARRICK, MD EDIN. $(1767-1837)$

$\begin{array}{rrrrr}\text { Date } & \text { Age } & \text { Annual Income } \\ & & f & s . \\ 1789 & 22 & 5 & \\ 189 & 23 & 107 & 15 & 0 \\ 1790 & 28 & 423 & 17 & 0 \\ 1795 & 33 & 823 & 2 & 0 \\ 1800 & 38 & 1,287 & 9 & 0 \\ 1805 & \text { Elected to the Bristol Infirmary as Honorary Physician } & 43 & & \\ 1810 & 48 & 2,321 & 1 & 0 \\ 1810 & 43 & 1,722 & 6 & 0 \\ 1815 & 53 & 2,165 & 8 & 0 \\ 1820 & 58 & 1,377 & 8 & 0 \\ 1825 & 63 & 877 & 3 & 0\end{array}$

Source: Bristol Royal Infirmary Biographical Memoirs, Vol. VIII, p. 645.

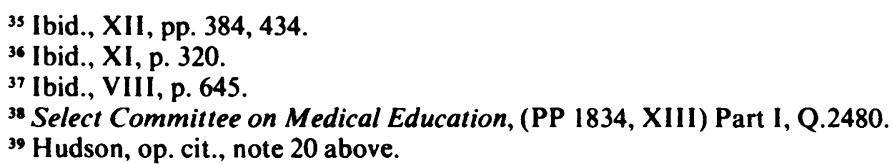




\section{S. L. Loudon}

Registration in 1847 stated that in his opinion, "I believe that there is no more meritorious class than the general practitioners of England, and I do not believe that there is any class who, in proportion to their education and their attainments, are so ill remunerated". ${ }^{40}$

One source of income open to general practitioners that has not so far been mentioned, were the various salaried posts, and in particular, the posts of "surgeon" or "medical officer" to the parish or union of parishes before and after the Poor Law Amendment Act of 1834. General practitioners were often enraged at the low salaries offered; nevertheless, within the context of the low incomes available from clinical practice, a post of Parish Medical Officer at $£ 50$ a year was a substantial addition to the practice income. This can be seen in the previous table showing Henry Peart's income in 1831, for this was the income he received as Parish Medical Officer.

Margaret Lamb, ${ }^{41}$ writing about the opportunities open to doctors in Glasgow in mid-nineteenth century, has stressed the importance of local government appointments. Her relatively optimistic accounts, however, of alternative sources of income should be balanced by Allison's ${ }^{42}$ (1844) searing account of medical relief for the poor in Scotland. This is a memorable account of neglect, cruelty, and intense meanness by the parish authorities. Many Scottish country general practitioners actually carried out medical work at a loss, for they were often paid nothing and supplied medicines and food out of their own pockets.

Nevertheless, in many parts of England, paid posts were important. Their importance is obvious from an amusing and informative account of an imaginary country practitioner (Dr Camomile) published in $1851 .{ }^{43} \mathrm{Dr}$ Camomile occupied "a square white house, neatly slated ... behind the house is the stable with two stalls, whose inmates are never destined to enjoy each other's society as Dr Camomile drives one about all day and rides the other round the country all night". He has great difficulty in making ends meet, although he has achieved an income of $£ 500-£ 600$ by acquiring all possible additional sources to his income. Thus he is "medical adviser in ordinary to the union in which he resides" and he has "contracted with the grammar school and the young ladies' boarding establishment in the adjacent town to keep the systems of the pupils cool and comfortable for an annual certain sum". He is "well with the squire; a sound Churchman and on dining terms with the Rector; and yet no violent partyman, lest the dissenting pneumonia of the country-side should fly for relief to the opposition brass plate in the county town". Much of the social history of the mid-nineteenth-century general practitioner is neatly encapsulated in this brief article.

\footnotetext{
${ }^{40}$ Select Committee on Medical Registration, (PP 1847, IX), Q.1536. Ibid. Q.211, G. J. Guthrie "nothing can be more contrary to good principles than to make education dear ... when the subsequent remuneration must in general be small; the great mass of country practitioners in England realising, in general, less than four hundred pounds a year".

"1 Margaret Lamb, 'The medical profession', in O. Checkland and M. Lamb, (editors). Health care as social history: the Glasgow case, Aberdeen University Press, 1982.

${ }^{42}$ W. P. Allison, Remarks on the Poor Laws of Scotland, 1844.

${ }^{43}$ 'Medical Intelligence. The income tax and its oppressive effects on the general practitioners', Prov. med. surg. J., 1851, 1: 111-112. (The article was re-published from The Times.)
} 
Our thesis has been that general practice in the 1820 s and 1830 s was an overcrowded branch of the medical profession in which the cost of medical education was disproportionately high, the difficulties of becoming established in practice considerable, and the income widely variable, but usually low. This is supported by the evidence of manuscript sources such as Henry Peart's cash book, and the substantial literature on medical reform that appeared in the first half of the nineteenth century. Is the thesis correct? Were the complaints of general practitioners echoed by equally loud and justifiable complaints from other professions? Were there not as many struggling clergy, school-teachers, solicitors, and members of the civil service? Musgrove has pointed out that the expansion of education for middle-class boys after the 1830s outstripped the opportunities for middle-class employment in general; and he produced some working definitions of the middle classes based on income levels. ${ }^{44}$ He took a salary range of $£ 200-£ 1,000$ as the salary of the middle classes after the mid-nineteenth century, which included "professional men, well-to-do clergy, the lesser gentry, superior tradesmen and industrial managers". From the evidence produced above, it is clear that some general practitioners achieved incomes in the lower reaches of this salary range, and a few in the upper. But it is likely that a majority of them, men like Henry Peart who practised in small country towns and villages, came into the salary range of $£ 60$ to $£ 200$ p.a.: a group of the lower middle classes that included "routine clerks, elementary school-teachers and lower officials of the civil service", none of whose parents would have had to meet anything approaching the cost of medical education. Hudson, whose knowledge of the medical profession in 1842 seems to have been comprehensive and accurate, believed that, "There is no profession in which it is so difficult to make a beginning as in that of medicine; and there is but too much truth in the vulgar saying that by the time when a physician earns bread and cheese he has no longer any teeth to eat them with". ${ }^{45} \mathrm{He}$ warned his readers that no young man, unless he had private means, should attempt to set up on his own in general practice; it might be that a year would pass before he had any patients. An assistantship was one way to start in practice, but, in a passage revealing for the comparison, he warned that whereas attorneys and solicitors earning $£ 2,000$ to $£ 3,000$ a year would pay their senior clerks $£ 300$ to $£ 400$ a year, a "surgeon apothecary in a good practice" seldom paid more than $£ 25-£ 30$ a year with board and lodging to an assistant.

There is a suggestion of an apparent paradox in general practice in the early

\footnotetext{
${ }^{44}$ Musgrove, op. cit., note 22 above; J. F. C. Harrison, The early Victorians 1832-1851 London, Weidenfeld \& Nicolson, 1971, p. 104, said that an income of $£ 300$ p.a. was frequently mentioned as the minimum necessary for the normal range of middle-class expectations. For the lower middle class, he quotes a range of $£ 150-£ 200$ p.a., while clerks and teachers at $£ 60$ p.a. would have been earning less than a skilled artisan. See also Lancet. 1830-1, i: 464, in which a Manchester practitioner suggested a scale of fees for attendance depending on whether the patients were "first class $=£ 400-£ 500$ p.a. and upwards, second class $=£ 200-£ 300$ p.a. or third class $=£ 100-£ 150$ p.a.". The same correspondent complained bitterly of the fellow practitioners who charged $1 s$. for all visits regardless of class of patient, and even stooped to collecting the fee in weekly contributions of $3 d$. and $6 d$.

is Hudson, op. cit., note 20 above.
} 


\section{S. L. Loudon}

nineteenth century. There was, as we have seen, great difficulty in establishing a practice and the likelihood of a low income when established. Yet general practitioners claimed that as the "new medical men" they were "the medical favourites of the community", ${ }^{46}$ trained scientifically in all branches of medicine and "tested by rigorous examination". They should, it seems, have been able to profit successfully from their improved status and education and from the increased wealth of their middle-class patients. Optimistically, they believed they could, and would, replace the physician except in a few large cities. Their optimism was not unreasonable.

There was indeed very little difference between physicians and general practitioners in the range of diseases they treated or the methods they used in the 1830s." Physicians were not specialists in the modern sense; the difference between themselves and general practitioners was based on claims which, in an age of increasingly scientific medicine, looked outdated and feeble. They were, they claimed, the natural leaders of the profession because of their higher social and general educational background, including a university education, ${ }^{48}$ and thus the doctors for the rich on all occasions and the consultants for cases of special difficulty. They claimed the right to higher fees, and they distanced themselves from the general practitioners by a refusal to undertake any manual activities and especially by the avoidance of the practice of pharmacy. When general practitioners began openly to advocate that, in cases of difficulty they should call in each other, rather than a physician, the special claims of the latter looked even more threatened.99 ${ }^{49}$ The physician had no greater skill or knowledge for the care of medical cases, and he was unable either to undertake the care of surgical conditions or dispense medicines for his patients. His higher status depended solely on being a more educated and cultured practitioner.

The "pure" surgeons, who practised nothing but surgery and refused to undertake either pharmacy or midwifery, were justified in their claim to a special position based on surgical skill, but there were very few of them. In 1834, out of the total of 8,000 members of the College of Surgeons, 7,800 were general practitioners and only 200 "pure" surgeons, nearly all practising in London. ${ }^{50}$ Honorary appointments at voluntary hospitals and dispensaries, although prestigious, had not assumed the central importance they would have later in the nineteenth century when, to an increasing extent, the physicians and surgeons were by definition hospital-based specialists and consultants. In fact, even as late as 1847 , nearly half the honorary posts in provincial hospitals and at least two-thirds of the posts in the dispensaries were held

\footnotetext{
46 Yeatman, op. cit., note 24 above.

${ }^{47}$ Charles Cowan, 'Reports of private medical practice', Lancet, 1841-2, ii: 358-361, 395-401, 433-439. These reports by a provincial physician on the staff of Reading Dispensary and the Royal Berkshire Hospital, show clearly that both the social class of patient and the spectrum of diseases treated by provincial physicians resembled very closely those treated by general practitioners. Only a few renowned physicians, mostly in London, confined their practice to the rich, and to providing second opinions in other cases.

4s Quart. Rev., 1840, 67: 53-79, and Select Committee on Medical Education, (PP 1834, XIII) Part I, Q.2482.

'Letter from 'A conservative', Lancet, 1839-40, i: 63. See also note 14 above.

so Select Committee on Medical Education, (PP 1834, XIII) Part II, Q.4731.
} 
by men describing themselves as general practitioners. ${ }^{31}$ It is not difficult to see why in the 1820s and 1830s the future looked hopeful to the younger generation of general practitioners. Many of them foresaw a reduction in the numbers and importance of both physicians and surgeons, and regarded the two Royal Colleges as reactionary stagnant institutions dedicated only to the preservation of out-dated special privileges. ${ }^{32}$ Wakley, through the Lancet, could have been the champion of general practice as well as the scourge of the physicians and surgeons, but he spoiled his case by a coarse, intemperate, long-winded approach (that he later regretted) even when, as often happened, he was right. Wakley was inspired by virulent hatred of the medical colleges and the teaching hospitals, showing little real interest in general practitioners except to use their difficulties as ammunition in his battles with the medical corporations.

The absence of a leader of any stature, and even more of a college or institution founded specifically by and on behalf of general practitioners was, as they realized at the time, a grave disadvantage. ${ }^{33}$ Nevertheless, in spite of a general atmosphere of conflict between general practitioners on the one hand and physicians and the "pure" surgeons on the other, the difficulties of general practice can only be attributed to a marginal extent to the opposition of the medical corporations. The control of the status and income of general practitioners was determined more by their patients than by their consultant colleagues. The simplest explanation of the poor state of general practice in the 1830s is the overcrowding of the profession. Too many general practitioners led to intense rivalry and low fees. With an average of less than 1,000 (perhaps 800) private paying patients per practitioner, an adequate income would have needed fees that were raised to unrealistic levels and very few "bad debts". Eight hundred patients is not enough; the fact that some general practitioners obtained a reasonable income, and a few a substantial one, condemned many others to poverty or bankruptcy.

The poor remuneration of general practitioners, stressed so often not just by themselves, but also by physicians and surgeons who were not generally sympathetically disposed towards them, had deeper roots. The history of the struggles of the apothecaries against the physicians weighed down general practitioners as they sought higher incomes and greater respectability in the eyes of patients and the profession. It was a legacy dating from the well-known case of the apothecary Rose, in

\footnotetext{
s1 Loudon, op. cit., note 2 above.

52 'Surgeon, apothecary and man-midwife. The state of the profession - General Practitioners', Lond. med. Gaz:, 1830, 6: 619-621.

${ }^{33}$ The result was the foundation of a large number of general practitioner associations during the first half of the nineteenth century, including the Association of Apothecaries and Surgeon Apothecaries (1812), which changed its name to the Association of General Medical and Surgical Practitioners in 1826; the Metropolitan Society of General Practitioners in 1830; the first British Medical Association founded by Dr Webster of Dulwich in 1836; and the National Association of General Practitioners in Medicine, Surgery and Midwifery founded in 1844, which gave rise to the National Institute of General Practitioners in 1846 that attempted (and failed) to found a Royal College of General Practitioners. All of these were short lived, and the only association to become permanent was the Provincial Medical and Surgical Association, which was open to all medical men and not only to general practitioners. It is, of course, the British Medical Association of today.
} 


\section{S. L. Loudon}

which by a decision of the Lords in 1704, apothecaries achieved the right to practise physic (i.e. to visit patients, give advice, and prescribe as well as dispense) but only to charge for the medicines supplied. ${ }^{54}$ The College of Physicians, previously vigorous in their prosecution of apothecaries, seemed to lose heart after the case. Apothecaries could, and sometimes did, charge for attendance with relative impunity, particularly in the country. But the legal decision established the custom. Patients, when visited and attended by an apothecary, expected to pay for their medicines only, and it was not until 1830 that the general practitioner, by the decision in the case of Handey $v$. Henson, obtained the legal right to charge for attendance as well as medicines. ${ }^{5 s}$ Even then, custom outlived the law. General practitioners continued in most instances to follow the out-dated custom of charging for medicines only, into the middle of the nineteenth century. It was a custom that had a profound and degrading effect on the nature of general practice, because it emphasized the financial dependence on the practice of pharmacy with undertones of the apothecary's shop.

Consequently, the general practitioner of the 1830 s made his living in very much the same way as the surgeon-apothecary of the eighteenth century. Study of day-books and account-books of provincial practitioners, whether in the 1770s or the 1830s and 1840 s, reveals the dependence of income on dispensing very large quantities of drugs, mostly of a harmless "placebo" nature. The surgical element of general practice is, and always has been, only a small part of the total, and even that small part consisted mainly of minor surgical procedures: the dressing of minor injuries, sores, and ulcers, opening abscesses, extracting teeth, and occasionally setting fractures and reducing dislocations. ${ }^{36}$ The title "surgeon-apothecary" simply demonstrates that all but a very small number of surgeons needed to practise as apothecaries to make a living, and also that apothecaries were perfectly capable of dealing with minor surgical conditions. ${ }^{37}$

Richard Smith junior of Bristol makes this abundantly clear:

About the year 1793 there were in Bristol 35 professed apothecaries and 20 surgeons - amongst the latter there were 8 or 10 who considered it 'infra dig' to put 'apothecary' upon their doors; yet the greater part even of these practised physic and dispensed medicines . . I commenced in business in 1795 ... was elected surgeon to the Infirmary in 1796 and in $1797 \mathrm{I}$ had painted 'Smith, Surgeon and Apothecary' upon my back door in Lamb St ... the front one, no: 17 in College Street had only

${ }^{54}$ Sir George Clark, A history of the Royal College of Physicians of London, Oxford, Clarendon Press, 1966, vol. 2, pp. 476-479.

ss Handey v. Henson, Court of King's Bench 9 January 1830. For reports of this case see, Lancet, 1829-30, i: 539, 571; Lond. med. phys. J., 1830, n.s. 7: 184-186; Med. chir. Rev., 1830, n.s. 12: 486-487. James Handey was a "Surgeon in practice before 1815" and described himself as "the first to try the legality of charge for visits from General Practitioners". (Churchill's London and Provincial Medical Directory, 1847). Clark (op. cit., note 54 above) mentions an earlier case: Fuller v. the executors of the Duke of Queensbury, p. 649, footnote. I have been unable to trace this case.

36 Manuscript sources on which these conclusions are based include: the account books of general practitioners in the library of the Wellcome Institute for the History of Medicine, London (MSS. 3584, 4702), and the day books in the private possession of Dr Dick Maurice of Marlborough. (For an account of the Maurice family practice see Dick Maurice, 'Six generations in Wiltshire', Br. med. J., 1982, 284: 1756-1758.)

${ }^{37}$ Joseph F. Kett, 'Provincial medical practice in England 1730-1815', J. Hist. Med., 1964, 19: 17-29. Yeatman, op. cit., note 24 above, and particularly $A$ general description of all trades (1747), which emphasizes the eighteenth-century tendency for apothecaries to practise surgery and physic as well as pharmacy, "especially in the country and often become Men of large Practice and eminent in their way". 
'Surgeon' ... in 1803 I attended all cases of fever, diarrhoea, phthisis, and in fact all cases purely medical as often as a patient chose to employ me .... A sickly large family was in those days an annuity of $£ 50$ - perhaps double the money. 38

Midwifery was a desirable part of practice only because it brought with it the whole family as patients; it was badly paid in the country and both time-consuming and exhausting. "I know of no surgeon", wrote Richard Smith, "who would not willingly have given up attending midwifery cases provided he could retain the family in other respects". 99 The way to maximize profits was to prescribe large quantities of medicine in small packages. Bottles containing four or six fluid ounces were labelled: "Take two tablespoons (one fl: oz:) two, [or three or four] times a day"; pills and electuaries were dispensed in ones, twos, or at most half a dozen; draughts were sent as single doses, made up individually. Ingredients were cheap and profits considerable. ${ }^{60}$

A striking example of profitability was the example of William Broderip, an apothecary with a large practice in Bristol in the late eighteenth and early nineteenth centuries. In 1796 his "business booked" amounted to $£ 5,993$, in $1797 £ 6,085$, and in $1798, \mathfrak{f 6 , 9 3 1}$. About a quarter to a third of his bills were never paid, but even when these bad debts were subtracted, his profits in 1798 amounted to $£ 4,668 .{ }^{61}$ Broderip, who practised neither midwifery nor surgery, made no charge for attendance in the City and only a minimal charge for journeys outside. Printed at the bottom of his bills was "attendance what you please". Many gave nothing, "but in one instance where the bill was $£ 30$ the patient added $£ 50 \ldots$ the loads of physic were beyond all thought", and the assistants in Broderip's shop worked until midnight in the winter. Richard Smith called this "the golden age of physic ... I do not believe there is at present [1830] more than one or two, perhaps not one practitioner, in the City of Bristol or Clifton who makes half the money". ${ }^{62}$ Incomes as high as Mr Broderip's may have been exceptional, ${ }^{63}$ but the ability of apothecaries and surgeon-apothecaries to make a substantial living from the practice of pharmacy was greatly diminished when, in the latter years of the eighteenth and the beginning of the nineteenth century, the dispensing druggists and chemists (the terms were interchangeable) increased in number. Dealing with the public directly, they undercut the "counter trade" of the apothecaries and in many instances usurped the traditional role of the apothecaries by dispensing for physicians. Even worse, physicians sometimes attended at the chemists' shops at stated hours to give advice "gratis" and prescribe, physician and chemist

\footnotetext{
s8 Bristol Royal Infirmary, op. cit., note 30 above. Vol. II, p. 152.

s9 Ibid., p. 157.

${ }^{60}$ For example, "The powders were chiefly rhubarb and prepared chalk with two or three grains of pulvis antimonalis ... a packet of twelve was charged four shillings - to grandees or where a costly charge might be made, a drop or two of cinnamon oil was added and rubbed up and then the packet was six or seven shillings - it was a fashion in those days to give musk when they could afford it . . so that you could smell it even in the street when you opened the door - in that case the bottles were charged - the draught $1 s$. $6 \mathrm{~d}$. the musk therein $10 s$. $6 d$. the profits upon these could not be much less than ten shillings a draught". Ibid., pp. 152-153.

${ }^{61}$ Ibid., p. 158.

62 Ibid., p. 159.

${ }^{63}$ E. M. Sigsworth and P. Swan, "An eighteenth-century surgeon and apothecary: William Elmhirst (1721-1773)', Med. Hist., 1982, 26: 191-198. Sigsworth and Swan record in some detail the income of William Elmhirst from his country practice. He earned approximately $£ 250$ per annum, compared to an average annual income in 1760 of $£ 100$ for innkeepers and lawyers and $£ 150$ for the wealthiest farmers.
} 


\section{S. L. Loudon}

dividing the profits. This happened in Bristol in the first decade of the nineteenth century: "Dispensing establishments began to multiply everywhere. . . In the year 1808 a respectable and well-connected apothecary made no more than $£ 700$ in a year", ${ }^{64}$ an income, incidentally, that would have delighted most provincial general practitioners twenty to thirty years later. The effect on William Broderip was devastating. He lost his town house and most of his furniture and pictures, his country residence near Westbury (known to the local population as "Gallipot Hall"), and by 1814 "it was generally buzzed about that 'Billy B.' was necessitous . . . if you chanced to pass him by in the street he hurried by under a confused salute and it was painful in the extreme ...". Broderip sank into poverty and died in 1824.

The rise of the dispensing druggist occurred all over the country, and led to a meeting of apothecaries in 1794 to protest at the encroachment of the druggists, not only in the metropolis, but "in all the towns and cities throughout the kingdom. Nor stopped the contagion here. From the larger cities and towns it was beheld propagating itself to smaller cities and towns, till at length so general was the disease, there was scarcely to be found a village or hamlet without a village or hamlet druggist."65 The General Pharmaceutical Association of Great Britain, founded at the meeting in 1794, was short lived and ineffective, but it was the first sign of the growing demand for reform of the medical profession. In 1805, the Lincolnshire Medical Benevolent Society appointed one of their number, Edward Harrison a physician from Horncastle, to undertake almost single-handed a programme of medical reform. The main objectives of the programme were the introduction of a uniform system of medical education and the suppression of "professed quacks and unauthorised practitioners". Harrison showed that in the Horncastle district of Lincolnshire there were five physicians (all graduates of Scotland), eleven surgeon apothecaries, and twenty-five druggists, of whom only one had served an apprenticeship. ${ }^{66}$

Harrison's attempts at reform were defeated by the implacable opposition of the College of Physicians (Harrison held neither the licence of the College nor the extralicence) and also by "Those who held privileges, and those who held none; those who believed themselves deprived of their rights and those who feared a change on the grounds that all change was dangerous who united into a phalanx, compact, formidable and impenetrable". ${ }^{67} \mathrm{He}$ was forced to give up in 1811 , but a year later the Association of Apothecaries and Surgeon Apothecaries was founded at a meeting held on 3 July 1812 when, at the instigation of Anthony Todd Thompson, the meeting turned from the original purpose of protesting at the new tax on glass to the subject of medical reform. Their ideas were clearly influenced by Harrison's, and they included

\footnotetext{
64 Bristol Royal Infirmary, op. cit., note 30 above, Vol: II, pp. 160-161.

os Jacob Bell, Historical sketch of the progress of pharmacy (1843), p. 29. See also, John Mason Good, The history of medicine so far as it relates to the profession of the apothecary, London, 1796, and in particular Robert Masters Kerrison, An inquiry into the present state of the medical profession in England, London, Longman, 1814, ch. VI, p. 39 et seq., and Edward Harrison, Remarks on the ineffective state of the practice of physic in Great Britain, London, 1806, pp. 14-15. George Man Burrows in the introductory essay to the Transactions of the Associated Apothecaries and Surgeon-Apothecaries (1823) dated the rise of the dispensing druggist from "thirty years ago", i.e. the 1790 s.

${ }^{66}$ Edward Harrison, An address delivered to the Lincolnshire Medical Benevolent Society, 1810, and op. cit., note 65 above.

${ }_{67}^{67}$ 'Sketch of the progress of medicine', Med. phys. J. 1811, 26: 2-5.
} 
in their Bill control of the druggist through a process of licensing. In this respect they were unsuccessful; the clauses relating to chemists and druggists were removed before the Bill, in its greatly amended form, became the Apothecaries' Act of $1815 .^{68}$

Unchecked by legal restraints, the chemists and druggists increased in numbers to the detriment of the general practitioners. Numerous accounts were published of the danger to the public of untrained unlicensed druggists who prescribed the wrong remedies and whose products, through ignorance or wilful dishonesty, were defective or made out of cheap substitute materials. Physicians were accused of collusion with chemists and receiving in return cash or gifts. Worst of all, it was asserted that druggists had taken to visiting patients and prescribing - in other words, they were "practising physic" and undercutting the general practitioner not only in "the shop" but outside it as well. ${ }^{69}$

It is difficult to say whether these accusations were true, and if so, how frequently. The published accounts often have the feel of apocryphal stories originating from anger and suspicion amounting sometimes to paranoia. To demonstrate the difference between themselves and the druggists (and their closeness to physicians) general practitioners renewed their insistence on the right to charge for visits, and drew up scales of charges. By 1834, they obtained widespread support in this respect from all branches of the profession. ${ }^{70}$ But the suggestion that they should abandon pharmacy altogether, ${ }^{11}$ although it would sever symbolically their link with the apothecaries, was too high a price to pay for the quality they desired most, professional respectability. The "GP" was a general practitioner in medicine, surgery, midwifery, and pharmacy, but in the first half of the nineteenth century the practice of pharmacy was, for the large majority, their main source of income.

In most accounts of the history of the early general practitioner, his status and low income are attributed simply and wholly to the belief that he evolved directly from the apothecary. It is implied that the original hierarchy of physician, barber-surgeon, and

\footnotetext{
68 Transactions of the Associated Apothecaries and Surgeon-Apothecaries of England and Wales, 1823, 1: and George Man Burrows, A statement of circumstances connected with the Apothecaries' Act and its administration, London, Callow, 1817 .

69 For accounts of these aspects of alleged behaviour by the dispensing druggists see Harrison (1806), Kerrison (1814), and Bell (1843), all cited in note 65 above; 'Medical reform', Lond. med. Repos., 1822, 16: 311-325; 'Physicians per-centage system', Lancet, 1828-9, ii: 591, 683-684; 'Surgeon and apothecary, Remarks on the Apothecaries' Act', Lond. med. phys. J., 1815, 35: 19-20; 'Of living biography', Gazette of Health, 1821, 6: 842 (in which it was alleged that a druggist in London rewarded the physicians who patronized him with haunches of venison); J. Black, 'On the reform of the medical profession', Prov. med. surg. J., 1840-1, 1: 147-149.

${ }^{70}$ Support for the principle that general practitioners should be able to charge for attendance as well as for dispensing was almost universal amongst the witnesses at the Select Committee on Medical Education, (PP 1834, XIII). See Part I, Qs. 265, 871, 3033, 3467, 3545; Part II, Qs. 4902, 5765, 5798-9, 6210, 6434, 6738; Part III Qs. 135, 329-332, 488.

$"$ This suggestion is included in the answers to many of the questions to witnesses in the report of the Select Committee on Medical Education (PP 1834, XIII); see also, 'Medical remuneration', Med.-chir. J., 1824, 5: 509-510 and 1825, n.s. 2: 246-248; 'Medical statistics and reform', ibid., 1834, 20: 567-571; leading article, Lancet, $1842-3$, i: 795.
} 


\section{S. L. Loudon}

grocer-apothecary survived essentially intact into the nineteenth century, maintained by the active opposition of the élite amongst the physicians and surgeons to any improvement in the lot of the general practitioner. Such an explanation is superficial. There were, of course, significant links with the apothecary, and there was some degree of active opposition from the medical corporations. But the general practitioner emerged during a period of intense upheaval and reform in the medical profession, and the factors which determined the future of general practice were complex. It has been the purpose of this paper to explore some, but - for reasons of space - by no means all, of these factors. The education of the general practitioner, for all its faults, was much more comprehensive and organized than anything that had existed in England and Wales (but not Scotland) before 1815, although it was expensive by comparison with the income that could be expected. Nevertheless, the early general practitioners were often inspired by an optimism, a pride in the breadth of their training, and a belief that they were the medical favourites of the community. The reality was different. They were dependent on the practice of pharmacy with its undertones of the shop trade. They were sometimes in conflict with the consultant physicians and surgeons, but more often they were involved in bitter rivalry with the dispensing druggists and other "irregular practitioners", and with their fellow practitioners in an overcrowded profession. Reader remarked perceptively: "Compared with the lawyers, acrimony between the various branches of the medical profession was greater. Barristers and attorneys seem to have been fairly amicable about sharing professional duties, vagaries and spoils. Doctors were far more quarrelsome, and perhaps some of the results are with us yet, particularly in the touchiness of GPs."'?2 It could be said that this paper has been concerned with the origins of that touchiness.

\section{ACKNOWLEDGEMENTS}

The author acknowledges with gratitude the support of the Wellcome Trust, and is especially grateful to Dr Joan Lane of the Centre for Study of Social History in the University of Warwick both for advice and for informing the author of the existence of Henry Peart's cash book.

\footnotetext{
$12 \mathrm{~W}$. J. Reader, Professional men: the rise of the professional classes in nineteenth-century England, London, Weidenfeld \& Nicolson, 1966.
} 